\title{
SPATIAL ANALYSIS OF RURAL GROWTH CENTRES IN SAGAR DISTRICT, MADHYA PRADESH
}

\author{
Pawan Kumar Sharma \\ Assistant Professor, Department of General \& Applied Geography \\ Dr. Hari Singh Gour University (A Central University), Sagar (M.P.), India \\ Email: pawansharmageo@gmail.com
}

\begin{abstract}
This paper aims to analyse the spatial pattern of rural growth centres in Sagar district with the help of nearest neighbour analysis. Rural growth centre is acts as a service centre, which has a potential for further development, and it provides services, goods and facilities for its own population and its surrounding area, which fulfilling their required needs and basic amenities for better livelihood. It conceived as a point of attraction for the people who otherwise would go to large congested urban areas. The present study is an attempt to find out the hierarchical order of settlements as rural growth centres, rural growth point, service centre and rural centres in the Sagar district. To find out this hierarchy, the composite score method has been applied for 40 selected socio-economic amenities. This study is based on secondary data, which are mainly collected from District census handbook 2011of Sagar district. The Social Amenity index is used to calculate weightage value of each facility. The nearest neighbour analysis method is used to found $R n$ value and deciding the spatial distribution pattern of rural growth centres in the study area. Total 38 Rural Growth centres are identified in the study region. As per the nearest neighbour analysis the $R n$ value is 0.151 , which shows that the $R G C$ 's are distributed in clustered pattern. The result reflects there is wide spread disparities in the block wise distribution of rural growth centres. So, there is an urgent need to propose some new Growth centres in the unserved gap areas to provide socio-economic activities to all the local people. It will be definitely slowdowns the migration from their surrounding habitat to larger urban areas, because rural centre work as a point of attraction of services. This idea of centre places is based on selectivity on the one hand and decentralization of social amenities on the other. Therefore an overall development of all villages within the region can be ensured in an integrated way at minimum cost in terms of money, time and effort.
\end{abstract}

Key words: Socio-Economic Amenity Index, Nearest Neighbour Analysis, Clustered Pattern

\section{Introduction}

In recent years, greater emphasis has come to be laid on grass-root approach to planning and a number of area development programmes were launched to meet this end. This research has an aim to achieve optimum results of rural development of Sagar district by a balanced distribution of highly necessary facilities. The core aspect of the study of rural central places is the identification of centres of different orders, which may provide an efficient way of articulating the development activities in different parts of the region. In the rural areas due to the scattered distribution pattern and small sized settlements, it is impracticable to provide all the functions in every settlement. It is, therefore, advisable to select centres, keeping in view the least travel distance and maximum population to serve, for locating the various functional institutions. These centres, which are of different orders, will act as nucleus for providing some basic packages of services to their hinterland according to their respective hierarchical orders. They may be arranged in to a spatial system for smooth transmission of various development activities throughout the region in such a way, as the friction of distance, the main constraint of exposure is minimized. They will much effective in eliminating the spatial lag of socio-economic growth in different parts.

The goals of rural development entail adequate concentration to various economic, social and political factors that influence the rural society through a complex network of interrelationship, where growth centre can be an eligible potential feature. The growth centres performs as centre of economic, social and cultural activities in the rural areas. A rural growth centre can be compared with Central Business District (CBD) of the arena. These are the 
venues where people at least fulfil their basic needs related to agricultural, educational, medical and marketing services. In India, nearly seventy percent of the total population of the country lives in rural areas that are facing the problems of lack of essential amenities for their livelihood. It is essential to insure the availability of basic necessities at minimum distance in least time frame. The importance of central place depends upon the central functions performed and the size of the population served by it. On the basis of functions and the size of the population served central places can be categorized into high order central places and low order central places. High order central places have large size of population served by it with greater functional specialization, whereas low order central places have small size of population served with smaller range of goods and services.

\section{Literature Review}

Rural growth centre is found as a growing spot of service delivery in the rural area and to bridge the gap between rural economy and regional economy, attention should be given regionally for growth centre development for the changing the rural people's livelihood style and sustainable development of the catchment area of the growth centre. The concept of microregional planning suggests a framework for decentralizing economic and social activities by locating specific functions in appropriate places. The central place is the most important aspect of the Christaller's theory. It is the centre of a region which provides one or more services to an area larger than itself. The services may be extensive or limited, but the service function is common to all central places. The criteria based on an assessment of the business and services for deciding the hierarchy of settlements was mainly used by Webb (1959), Dickinson(1964), Parkes (1969), Clout (1972) and Carter (1972). Guttman's Scalogramme technique (Parkes, 1969) is more applicable in Indian context because in India number or isolation is found in physical landscape. In India also, a number of geographers like, L.K. Sen (1971), L.S. Bhatt (1972), R. C. Sharma (1972), A.B. Mukerjee (1974), J. Singh (1979), Sundaram (1980), C. R. Kothari (2001), R. P. Mishra (2002), R. N. Mishra and P.K. Sharma (2004) have identified growth centres and their hierarchy by measuring the centrality in different ways. R.P. Mishra has applied centrality score method to suggest a five-tier hierarchy of growth foci as Growth Pole, Growth Centres, Growth Point, Service Centre and Central Village. R. N. Mishra and P.K. Sharma (2004) have applied a Final Centrality Score by adding Functional Index value of Webb and Social Amenity Index value by L.S. Bhatt for identification of hierarchical arrangement of the settlements. In the present study, the whole settlements of the district are classified into four tier hierarchical order. A rural growth centre is a village, which provides one or more services for the population living around it. V.L.S. Prakasa Rao explained the concept of central place as the crystallization of mass around a nucleus, which may be a town and is the focal point for its surrounding area. Sharma, P.K. (2018), focused on this study of rural development scenario and strategies in Bundelkhand region of Madhya Pradesh. Sharma, P.K. \& Sharma, S.C. (2016), studied or analysed the rural central places is a new perspective for micro-level development planning.

\section{Study Area}

Sagar District is a district of Madhya Pradesh state in central India. It is situated between 23॰10' to $24 \circ 27^{\prime}$ north latitude and $78^{\circ} 4^{\prime}$ to $79^{\circ} 21^{\prime}$ east longitude. Sagar district is a sixteenth largest district in size in the state, and third largest in the Jabalpur revenue division. As of the census 2011, Sagar District had a population of 23, 78, and 458 persons of which male and female were 12, 56, 257 and 11, 22, 201 respectively. The average literacy rate is 76.46 percent in 2011 compared to 67.73 percent of 2001 . The major share of the population is belongs to Rajgonds tribes. The district has 2075 in-habitated villages as per the census 2011.

\section{Objective}

The present research aims to study about the rural growth centres of Sagar district with the help of nearest neighbour analysis. The major objectives of the study are:

1. To analyse the salient features of rural development in its geographical frame.

2. To identify the Rural Growth Centres in the study area.

3. Nearest Neighbour Analysis to investigate the block wise spatial pattern of rural growth centres.

4. To formulate the plan for the balance development of the region. 


\section{Database and Methodology}

The study is related to rural central places, so primary data have been collected at the village level and secondary level data have been collected for resources and infrastructure development from various departments. The statistical as well as empirical methodologies are used to obtain the aim of this study. The study followed personal interview, Focus group discussion and key informant interview for collection of information and secondary data from Census of India (2011) and statistical handbook of Madhya Pradesh, reference books, journals and various documents. As per the methodological aspect this study have two phases, at the first stage rural growth centres are identified by using social amenity index method whereas in second stage the spatial arrangement of these centres are analysed through Nearest Neighbour matrix. In this study 40 functions found in the total settlements of the study area have been taken into consideration.

Therefore, this method is based on two factors like Number of different functions offered by a settlement (quantity) and the Level of various functions available in a settlement (quality).

(a) Social Amenity Indies (SAI) - It is based on central facilities found in the settlement like education, medical, marketing, postal etc. For finding SAI we have to find out weightage for each facility.

To find out weightage following formula has been used: $W=N / F$

Where; $\mathrm{W}=$ Weightage of each facility. $\mathrm{N}=$ Total number of settlement in the study area. $F=$ Number of settlement having that particular facility.

The weightage value has been calculated for all the amenities. According amenities are arranged in an order as in ascending order.

Table 01: Facilities with their Weightage Value

\begin{tabular}{|l|l|l|l|l|l|}
\hline$\#$ & Name of Facility & $\begin{array}{l}\text { Weightage } \\
\text { Value }\end{array}$ & $\#$ & Name of Facility & $\begin{array}{l}\text { Weightage } \\
\text { Value }\end{array}$ \\
\hline 1. & Primary School & 1.26 & 21 & Mobile Phone Coverage & 1.38 \\
\hline 2. & Middle School & 2.77 & 22 & Bus Service (Public \& Private) & 3.48 \\
\hline 3. & Secondary School & 16.08 & 23 & Railway Station & 56.08 \\
\hline 4. & Senior Secondary School & 23.57 & 24 & Sea/ River Ferry Service & 32.42 \\
\hline 5. & Primary Health Centre (PHC) & 94.31 & 25 & $\begin{array}{l}\text { Connected to National Highway } \\
\text { (NH) }\end{array}$ & 18.36 \\
\hline 6. & $\begin{array}{l}\text { Primary health sub centre } \\
\text { (PHS) }\end{array}$ & 14.02 & 26 & $\begin{array}{l}\text { Connected to State Highway } \\
\text { (SH) }\end{array}$ & 12.88 \\
\hline 7. & $\begin{array}{l}\text { Maternity and child welfare } \\
\text { centre (MCW) }\end{array}$ & 148.21 & 27 & $\begin{array}{l}\text { Connected to major district road } \\
\text { (MDR) }\end{array}$ & 6.17 \\
\hline 8. & Dispensary (D) & 51.87 & 28 & Pucca roads & 2.4 \\
\hline 9. & Veterinary hospital (VH) & 79.8 & 29 & $\begin{array}{l}\text { Commercial \& Co-operative } \\
\text { Banks }\end{array}$ & 41.5 \\
\hline 10. & Family welfare centre (FWC) & 86.45 & 30 & Agricultural Credit Societies & 12.2 \\
\hline 11. & Tap Water & 5.76 & 31 & Self-Help Group (SHG) & 2.02 \\
\hline 12. & Well Water & 1.14 & 32 & $\begin{array}{l}\text { Public distribution system (PDS) } \\
\text { shop }\end{array}$ & 3.26 \\
\hline 13. & Hand Pump & 1.12 & 33 & Mandis / Regular Market & 74.1 \\
\hline 14. & Tube Well / Bore Well & 3.32 & 34 & Weekly Haat & 25.93 \\
\hline 15. & River / Canal & 3.49 & 35 & Agricultural Marketing Society & 44.14 \\
\hline 16. & Tank/Pond/ Lake & 4.96 & 36 & $\begin{array}{l}\text { Integrated Child Development } \\
\text { Scheme }\end{array}$ & 7.6 \\
\hline 17. & Post Office (PO) & 18.2 & 37 & Anganwadi Centre & 1.56 \\
\hline 18. & Sub-Post Office (SPO) & 15.6 & 38 & $\begin{array}{l}\text { ED- Power Supply for Domestic } \\
\text { Use }\end{array}$ & 1.14 \\
\hline 19. & $\begin{array}{l}\text { Post \& Telegraph office } \\
\text { (P\&TO) }\end{array}$ & 29.64 & 39 & $\begin{array}{l}\text { EAG- Power supply for } \\
\text { agricultural use }\end{array}$ & 1.15 \\
\hline 20. & Telephones (Land Lines) & 7.43 & 40 & EA- Power Supply for ALL uses & 1.44 \\
\hline & & & & \\
\hline
\end{tabular}

Total 40 basic facilities have been taken into consideration to calculate the weightage score for the each settlement. These facilities are generally related with basic amenities of any area, such as - education, health, drinking water, market, electricity, agriculture, transport, communications and some of the essential government services etc. Weightage value is measured for each facility of every village. After then final composite score is calculated for each centre. 
On the basis of final centrality score all the settlements of the study region has been classified into four categories as Rural growth centres, Rural growth points, Rural service centres and central Village which are show in the table 2.

Table 02: Hierarchical Order of Rural Growth Centres of Sagar District

\begin{tabular}{|l|l|l|c|}
\hline$\#$ & Hierarchical Order & Social Amenity Index & No. of Villages \\
\hline 1. & Rural Growth Centre (RGC) & Above 6.00 & 38 \\
\hline 2. & Rural Growth Point (RGP) & $3.00-6.00$ & 89 \\
\hline 3. & Rural Service Centre (RSC) & $1.00-3.00$ & 412 \\
\hline 4. & Central Village (CV) & Below 1.00 & 1536 \\
\hline
\end{tabular}

Total 38 Rural Growth centres are found in Sagar district, having the social amenity index score above or up to 6.00. The villages having the index values between 3.00 to 6.00 are consider as rural growth points. The total 89 villages are under the category of rural growth points. Rural service points are 412 (based on scale value 1.00-3.00) and remaining centres are called as Central villages (1536) which are in the range of 1.00 or below 1.00 according to Social Amenity index value.

Table 03: Block wise distribution of Rural Growth Centres in Sagar District

\begin{tabular}{|l|l|c|c|c|c|}
\hline$\#$ & Block & RGC & RGP & RSC & CV \\
\hline 1 & Bina & 2 & 7 & 36 & 132 \\
\hline 2 & Khurai & 3 & 6 & 30 & 148 \\
\hline 3 & Malthon & 6 & 4 & 27 & 156 \\
\hline 4 & Banda & 0 & 10 & 38 & 131 \\
\hline 5 & Shahgarh & 6 & 6 & 28 & 88 \\
\hline 6 & Rahatgarh & 4 & 12 & 51 & 144 \\
\hline 7 & Jaisinagar & 4 & 2 & 39 & 104 \\
\hline 8 & Sagar & 4 & 14 & 43 & 101 \\
\hline 9 & Rehli & 1 & 15 & 40 & 145 \\
\hline 10 & Kesli & 4 & 7 & 33 & 197 \\
\hline 11 & Deori & 4 & 7 & 47 & \\
\hline
\end{tabular}

${ }^{\star}$ RGC= Rural Growth Centres RGP= Rural Growth Points Rsc= Rural Service Points CV= Central Villages

As per the hierarchical order there are total 38 Rural growth centres in 11 blocks of the Sagar district, with 6 RGC's Malthon and Shahgarh blocks have highest number of rural growth centres in comparison to other block of the Sagar district. After these Sagar, Rahatgarh, Jaisinagar, Kesli and Deori blocks having 4 RGC's, Khurai block has 3 RGC's and Bina block having 2 centres whereas the Rehli block have only one such centre and Banda block is without of any rural growth centre. These values are given in table 4.

\section{Nearest Neighbour Analysis}

Nearest neighbour analysis (NNA) is applied for finding the spatial distribution of rural growth centres in the district. The evolution of spatial pattern is the result or diverse geographical setting. Hence, they have varying patterns of spatial distribution in different geographical region. The settlement patterns on the earth surface consequent upon the geographical setting, rare found in uniform pattern. NNA method is firstly introduced by P. Hertz in 1909, but its systematic use was done by Clark \& Evans (1954) in context of two-dimensional measurement of the phenomena distributed over the surface of earth. They used this method to measure distribution of different plants in different regions. Nearest Neighbour Analysis measures the distribution of something over a geographical space. It provides a numerical value that describes the extent to which a set of points are clustered or uniformly spaced. Nearest neighbour analysis examines the distances between each point and the closest point to it, and then compress there to expected values for a random sample of a points from a complete spatial randomness (CSR) pattern. This expresses distinction of spatial patterns of points in a scientific and numerical form. It distinguished spatial pattern as -Uniform, Random and Clustered. 
Table 04: Rural Growth Centres in Sagar District

(Based on Final Composite Score above FCS 6)

\begin{tabular}{|c|c|c|c|c|c|}
\hline Block & $\#$ & $\begin{array}{l}\text { Rural Growth } \\
\text { Centres }\end{array}$ & $\begin{array}{l}\text { Area } \\
\text { (Sq. Hectare) }\end{array}$ & $\begin{array}{l}\text { Total } \\
\text { Population }\end{array}$ & $\begin{array}{l}\text { Final Composite } \\
\text { Score }\end{array}$ \\
\hline \multirow[t]{2}{*}{ Bina } & 1 & Bhangarh & 1161.7 & 3516 & 9.38 \\
\hline & 2 & Agasod & 1985.6 & 4495 & 7.24 \\
\hline \multirow[t]{3}{*}{ Khurai } & 1 & Khimlasa & 1149.8 & 10333 & 16.49 \\
\hline & 2 & Basahari & 3797.2 & 7138 & 6.61 \\
\hline & 3 & Bardha & 1402.9 & 2593 & 6.09 \\
\hline \multirow[t]{6}{*}{ Malthon } & 1 & Malthon & 777.8 & 10764 & 23.57 \\
\hline & 2 & BandriKaroli & 1208 & 10802 & 17.34 \\
\hline & 3 & Barodiya Kalan & 2014.4 & 6836 & 10.60 \\
\hline & 4 & Rajwans & 978 & 2830 & 10.23 \\
\hline & 5 & Pithoriya & 848.6 & 3678 & 6.94 \\
\hline & 6 & Rouda & 1354.5 & 2328 & 6.37 \\
\hline \multirow[t]{6}{*}{ Shahgarh } & 1 & Barayatha & 994.2 & 4976 & 14.51 \\
\hline & 2 & Dalpatpur & 735.9 & 5096 & 11.40 \\
\hline & 3 & Khatora Kalan & 903.4 & 2944 & 8.60 \\
\hline & 4 & Hirapur & 125.9 & 17 & 8.35 \\
\hline & 5 & Narwan & 2589.8 & 7355 & 7.03 \\
\hline & 6 & Amarmaoh & 1515.5 & 5550 & 6.19 \\
\hline \multirow[t]{4}{*}{ Rahatgarh } & 1 & Narayawali & 1179.9 & 5261 & 18.26 \\
\hline & 2 & Sihora & 1497 & 5355 & 17.26 \\
\hline & 3 & Mudra Jaruwakheda & 1072.6 & 6521 & 13.72 \\
\hline & 4 & Jhila & 1801.8 & 3760 & 6.97 \\
\hline \multirow[t]{4}{*}{ Jaisinagar } & 1 & Jaisinagar & 1083.1 & 7848 & 14.89 \\
\hline & 2 & Bilehra & 1920.6 & 9371 & 12.65 \\
\hline & 3 & Chartoriya & 637.8 & 1680 & 7.45 \\
\hline & 4 & Bakswaha & 1127.3 & 1553 & 6.72 \\
\hline \multirow[t]{4}{*}{ Sagar } & 1 & Surkhi & 2079 & 7289 & 17.72 \\
\hline & 2 & Sanodha & 1952.8 & 6394 & 13.74 \\
\hline & 3 & Parsoriya & 538.9 & 4398 & 9.24 \\
\hline & 4 & Kerbana & 1062.2 & 4121 & 7.54 \\
\hline Rehli & 1 & Chhirari & 1231.8 & 4336 & 9.72 \\
\hline \multirow[t]{4}{*}{ Kesli } & 1 & Kesali & 493.5 & 8565 & 21.38 \\
\hline & 2 & Tada & 694.8 & 2682 & 14.75 \\
\hline & 3 & Sahajpur & 234.6 & 529 & 7.78 \\
\hline & 4 & Keolari & 436.2 & 1001 & 7.10 \\
\hline \multirow[t]{4}{*}{ Deori } & 1 & Mahrajpur & 696.9 & 4946 & 17.15 \\
\hline & 2 & Gaurjhamer & 578.2 & 9746 & 13.59 \\
\hline & 3 & MardhiJamuniya & 574.5 & 3006 & 8.53 \\
\hline & 4 & Jhunku & 217.1 & 2974 & 6.78 \\
\hline
\end{tabular}

\section{Nearest Neighbour Index}

It measures the distribution of any spatial pattern or points from randomness assuming the distribution of points on random. It is also known as an index of randomness.

It represents the ratio between the mean observed distance or points and the mean expected distance in random situation.

$$
\mathrm{Rn}=\frac{\text { Do }}{\text { De }}
$$

Where; Do = Observed distance shows the average distance between all points or all places whereas Expected distance

$\mathrm{De}=$ shows the intensity of all patterns/ sample.

NNA is helps to determine the spatial pattern and intensity of variables of service centre or growth centre. In geography analysis, first of all this method was used by Dacey to study the distribution of settlement pattern.

$\mathbf{R}=\mathrm{ro} / \mathrm{re}$

Where; $R=$ Nearest Neighbour Constant

$\mathrm{r}=$ = Average Observed Distance

$\mathrm{re}=$ Average Expected Distance

$\mathrm{ro}=\sum \mathrm{d} / \mathrm{N}$ 
$\mathrm{d}=$ distance between any settlement and their nearest settlement (where direction is not focused)

$\sum \mathrm{d}=$ summation of nearest distance of various settlement.

$\mathrm{N}=$ total no. of all settlement

$r e=1 / 2 \sqrt{ } / A$

$A=$ total area of study region

The value of ' $R$ ' is always comes between 0.00 to 3.00. On the basis of these values' tendency of distribution of settlement pattern will be defined. The final value put in the Scale for measuring distribution pattern of settlements (Rn scale)

Table 05: Rn Scale

\begin{tabular}{|l|c|}
\hline Rn value & Spatial Pattern \\
\hline $0.00-0.09$ & Complete concentration \\
\hline $0.10-0.50$ & High concentration \\
\hline $0.51-0.99$ & Clustered pattern \\
\hline $1.00-1.19$ & Random pattern \\
\hline $1.20-1.49$ & Approaching uniform \\
\hline $1.50-2.14$ & Dispersed pattern \\
\hline 2.15 & Hexagonal pattern \\
\hline $2.15 \&$ above & High dispersed pattern \\
\hline
\end{tabular}

Value of $r$ also compared with other statistical method. In this variance, Index $(V)$ is important.

$V=(4-\pi) / 4 d \pi$

Where;

$\pi=22 / 7$ or 3.1416

$\mathrm{d}=\mathrm{N} / \mathrm{A}=$ no. of settlement $/$ total area of study region

Complete the Analysis of $\mathrm{V}$ value is with the expected distance (re) which is like that

$-$

If $r e>v$, (uniform distribution)

$\mathrm{V}>\mathrm{re}$, (clustered pattern)

$\mathrm{Re}=\mathrm{v}$ or $\mathrm{re} / \mathrm{v}=1$, then always be (random pattern)

Uses- This method is very useful to show the spatial pattern of the settlements.

It also used to show the settlement distribution based on different population groups. In any area distribution of multiple facilities also measures by used this method. Its outcome is to make planning for distribution of equal facility according their needs. So, it plays important role to making plans of equal distribution of facilities in any area.

Table 06: Distance between Rural Growth Centres

\begin{tabular}{|l|l|c|c|l|l|c|c|}
\hline$\#$ & $\begin{array}{l}\text { Rural Growth } \\
\text { Centres }\end{array}$ & $\begin{array}{c}\text { Nearest } \\
\text { Growth } \\
\text { Centre }\end{array}$ & $\begin{array}{c}\text { Distance } \\
\text { (in cm.) }\end{array}$ & $\#$ & $\begin{array}{l}\text { Rural } \\
\text { Growth Centres }\end{array}$ & $\begin{array}{c}\text { Nearest } \\
\text { Growth } \\
\text { Centre }\end{array}$ & $\begin{array}{c}\text { Distance } \\
\text { (in cm.) }\end{array}$ \\
\hline 1 & Bhangarh & $1-2$ & 1.0 & 20 & Jaruwakheda & $20-18$ & 1.3 \\
\hline 2 & Agasod & $2-4$ & 0.9 & 21 & Jhila & $21-20$ & 2.2 \\
\hline 3 & Khimlasa & $3-4$ & 0.8 & 22 & Jaisinagar & $22-24$ & 1.6 \\
\hline 4 & Basahari & $4-5$ & 0.8 & 23 & Bilehra & $23-25$ & 0.5 \\
\hline 5 & Bardha & $5-4$ & 0.8 & 24 & Chartoriya & $24-23$ & 0.6 \\
\hline 6 & Malthon & $6-8$ & 1.2 & 25 & Bakswaha & $25-23$ & 0.5 \\
\hline 7 & BandriKaroli & $7-10$ & 1.1 & 26 & Surkhi & $26-23$ & 1.2 \\
\hline 8 & Barodiya & $8-9$ & 1.2 & 27 & Sanodha & $27-29$ & 0.7 \\
\hline 9 & Rajwans & $9-8$ & 1.2 & 28 & Parsoriya & $28-27$ & 1.3 \\
\hline 10 & Pithoriya & $10-7$ & 1.1 & 29 & Kerbana & $29-27$ & 0.7 \\
\hline 11 & Rouda & $11-9$ & 1.2 & 30 & Chhirari & $30-37$ & 2.2 \\
\hline 12 & Barayatha & $12-14$ & 1.6 & 31 & Kesali & $31-32$ & 1.2 \\
\hline 13 & Dalpatpur & $13-14$ & 0.7 & 32 & Tada & $32-31$ & 1.2 \\
\hline 14 & Khatora & $14-13$ & 0.7 & 33 & Sahajpur & $33-31$ & 1.5 \\
\hline 15 & Hirapur & $15-16$ & 1.0 & 34 & Keolari & $34-24$ & 1.1 \\
\hline 16 & Narwan & $16-17$ & 1.0 & 35 & Mahrajpur & $35-38$ & 1.7 \\
\hline 17 & Amarmaoh & $17-15$ & 0.9 & 36 & Gaurjhamer & $36-37$ & 0.7 \\
\hline 18 & Narayawali & $18-19$ & 1.3 & 37 & MardhiJamuniya & $37-36$ & 0.7 \\
\hline 19 & Sihora & $19-18$ & 1.3 & 38 & Jhunku & $38-36$ & 1.6 \\
\hline
\end{tabular}


Formula to finding the nearest neighbour analysis- $\mathbf{R n}=\mathbf{D o} / \mathbf{D e}$

Where, $\mathrm{Rn}=$ the index of Randomness

Do $=$ the mean observed distance

Where; $\mathrm{Do}=\sum \mathrm{d} / \mathrm{N}=\mathrm{d} 1+\mathrm{d} 2+\mathrm{d} 3+$ $\mathrm{dn} / \mathrm{N}$

$\mathrm{Do}=\sum \mathrm{d} / \mathrm{N}=169.2 / 38=4.452$

$\mathrm{De}=$ the mean expected distance

Where; $\mathrm{De}=1 / 2 \sqrt{\mathrm{N}} / \mathrm{A}=1 / 2 \sqrt{38} / 10,252=1 / 0.034=29.411$

$\mathrm{De}=29.411$

$\mathrm{Rn}=\mathrm{Do} / \mathrm{De}=4.452 / 29.411=0.151$

Rn Score $=0.151$

Total distance $=42.3 \mathrm{~cm}$

$=42.3 \times 4=169.2 \mathrm{~km}^{2}$

Total area $=10,252 \mathrm{~km}^{2}$

\section{Result and Discussion}

In the present research, all the settlements of the study region are categorised in a hierarchy manner as rural growth centres, rural growth point, service centre and central village. On the basis of the final composite score of 40 basic socio-economic amenities total 38 villages are considered as rural growth centres in 11 blocks as they score the index value more than 6.00 . The Social Amenity index is used to calculate weightage value of each facility. The nearest neighbour analysis method is used to find $\mathrm{Rn}$ value and deciding the spatial distribution pattern of rural growth centres in the study area. The result reflects block wise distribution of rural growth centre in Sagar district. As per the nearest neighbour analysis the $R n$ value is 0.151 , which shows that the RGC's are distributed in clustered pattern. Overall the distribution is quite satisfactory in reference to the whole district but some of the area having not a single growth centres to serve the local population. Few areas are having sufficient rural growth centres as their population requirements are Malthon, Shahgarh, Sagar, Rahatgarh, Jaisinagar, Kesli, and Deori. Whereas some areas are having a few numbers of rural growth centres in Sagar district such as Khurai, Bina, Rehli, and Banda block is only block which is not having any rural growth centre. This kind of distribution of RGC's in the area is one of the reasons of spatial imbalance in the level of development among the Blocks of a district. The main strategy of rural growth centre approach is to reduce micro regional imbalance between rural and urban areas and to provide the minimum basic facilities to the each centre.

\section{Conclusion}

It is clear that the spatial arrangement of rural growth centres is an important tool through which the quality of life in human settlement can fairly be improved because such a system provides various facilities within easy reach of the people, in a lesser time and at least distance. Rural growth centre is a centre, which provides the facilities, services and goods to its own population as well as surrounding population for creating balance in socio-economic development in an area. In the present study the result shows that the maximum concentration of the facilities are found in the big size villages or in the urban centres whereas small village are lagging behind. It is recommended that the policy maker should ensure before the plan formation that at least accessibility basic amenities for the all local people at minimum distance with least cost for their respectable livelihood. This research suggests that there is an urgent need of establish some new rural growth centres in backward rural areas to fulfil their basic socio-economic requirements. Finally it is concluded with the fact that the development plans can better serve through rural transformation and their resourceful functioning at village level.

Acknowledgement: ICSSR for providing fund for the research under Major Research Project.

\section{References}

1. Agarwala, A.K. and Hazarika, P.L. (2002) Regional Disparities in Economic Development of Assam: A District level Study, Indian, Journal of Regional Science, Vol.34, No. 2, pp.121

2. Arora, R.C. (1979) Integrated Rural Development, S. Chand and Co. Ltd., New Delhi.

3. Bhatt, L.S. (1972) Micro level Planning, K.B. Publication, New Delhi. Pp.25-39

4. Census of India, (2011) District Census Handbook, Sagar, Directorate of Census Operation, Madhya Pradesh, Bhopal. 10-27 
5. Chand, M. and Puri, V.K. (1983) Regional planning in India, Allied publishers, New Delhi.

6. Christaller, W., 'Central Places in Southern Germany', translated by C.W. Baskins, London, Prentice-Hall, 1933.

7. District Statistical Outline (2013) District Sagar, Directorate of Economics and Statistic, Govt. of M.P., Sagar. Pp. 23-45

8. Mandal, R.B. (1979) Introduction to Rural Settlements, Concept Publication Company, New Delhi. pp. 46-51

9. Mishra, R.N. \& Sharma, P. K. (2003) Study of Rural Growth Centres for in Jaisalmer district, Journal ANNALS, Vol. XXIII, NAGI. New Delhi

10. Mishra, R.N. \& Sharma, P. K. (2007) Rural Growth Centres for Micro-level planning, Ritu Publication, Jaipur. Rajasthan. pp. 16-25

11. Mitra, A (1961) Levels of Regional Development in Census of India, Govt. of India, New Delhi, vol. 1 Part 1

12. Mondal, B.K. \& Das, K., (2010) Role of growth centre: A rural development perspective, journal of Bangladesh Institute of Planners, vol. 3, December 2010, p.p.129-141.

13. Pal, M.N. (1975) Regional Disparities in The Level Of Development In India, Indian Journal Of Regional Science, Vol.7. pp.34-39

14. Sethy, V. (2016) Regional Disparities in India: Top Eight Indicators, Sage Publication. Pp.79-83

15. Shand, $R$ and S. Bhide (2000) Sources of Economic Growth-Regional Dimensions of Reforms, Economic and Political Weekly, October 14, pp. 3747-3757.

16. Sharma, P.K. \& Sharma, S.C. (2016) 'Study of rural central places for micro-regional planning in Bikaner district' Annals of the RGA, vol. XXXIII.

17. Sharma, P.K. (2015) Regional Disparities in Socio-Economic Development in Jaisalmer District, Rajasthan, The Deccan Geographer. Vol. 53 (1), pp. 23-28.

18. Sharma, P.K., (2018) Rural development scenario and strategies in Bundelkhand Region of Madhya Pradesh, India, American journal of Rural Development, 2018, vol.6, No.3, 104108.

19. Singh, R. (2006) Regional Disparities in level of socio-economic Development in post Reforms Period: A District level Analysis, Annals of NAGI, Vol. 26, Dec., No.2, pp.8794.the International Trade." Journal of Economic Geography

20. Tiwari, R.C. (1997) Settlements Geography, Prayag Pustak Bhawan, Allahabad. 56-92

21. www.acadiemia.edu

22. www.sodhganga.inflibnet.ac.in/bitstream

23. www.vpic.info/publication/reports/imp/mentation/growth.pdf

24. www.yourarticlelibrary.com/geography/growth 